\title{
Efektifitas Praktikum Multimedia Struktur Atom dalam Mengatasi Miskonsepsi Kimia Anorganik Mahasiswa
}

\author{
Suyanti Dwi Retno \\ Kimia Anorganik FMIPA UNIMED Medan, email:dwi_hanna@yahoo,com \\ Sugyarto, HK \\ Kimia Anorganik FMIPA UNY Yogyakarta, \\ email: kristiansugiyarto@yahoo.com
}

\begin{abstract}
Abstrak: Tujuan penelitian ini dimaksudkan untuk memperoleh informasi tentang kemampuan inquiry mahasiswa dalam menelusuri bagaimana para pakar kimiawan menemukan tetapan Rydberg sehingga tidak terjadi miskonsepsi dalam memahami struktur atom khususnya dan Kimia Anorganik pada umumnya. Penelitian ini dilakukan di Jurusan Kimia FMIPA UNIMED dengan mengintegrasikan praktikum multimedia dan pembelajaran Kimia Anorganik. Hasil penelitian menunjukkan.terdapat peningkatan pemahaman mahasiswa dalam mempelajari struktur atom karena miskonsepsi terhadap tetapan Rydberg dan pembentukan spektrum Hidrogen dari ke empat ligan teratasi.

Kata kunci: praktikum multimedia, struktur atom, miskonsepsi kimia, tetapan Rydberg, dan persepsi mahasiswa

Abstract: This research aims to determine shell atomic energy related How finding Rydberg Constanta. This research was be held on Deparment of Chemistry Medan State University. Through Anorganic teaching and learning integrated with multimedia practikum, several misconception in atomic structure atomic has been overcome. The Efectivity of Multimedia Practicum in Atomic Structure for Overcoming Students Misconception Anorganic Chemistry. This research try to present discussion direct material in Inorganic Chemistry include atomic structure. The result of this research shows that there is skill student improving in learning atomic structure because of misconception trhough Rydberg's role and occuring hydrogeen spectrum from the fourth step.
\end{abstract}

Key words: Practical Multimedia, Structur atomic, Constanta Rydberg, Students Perception.

\section{Pendahuluan}

Kegiatan laboratorium (praktikum) merupakan salah satu kegiatan pembelajaran Kimia selain "class teaching". Ilmu kimia dibangun dari sebagian besar hasil-hasil penelitian laboratorium, maka kegiatan praktikum merupakan kegiatan pembelajaran yang sangat vital baik dalam memahami maupun mengembangkan ilmu kimia. Semakin "lengkap-variatif"suatu kegiatan praktikum, semakin mendekati ciri hakiki ilmu kimia itu, sehingga pembelajaran kimia selalu "didampingi" dengan kegiatan praktikum.

Keterbatasan dana/fasilitas, umumnya menjadi kendala utama minimnya kegiatan praktikum kimia, karena umumnya material kimia bersifat sebagai barang habis pakai. Oleh karena itu, pengembangan suatu model, khususnya model kemas-rapat geometri, merupakan salah satu alternatif yang dipandang sangat tepat untuk pembelajaran geometri kristal kimiawi, dan ini dapat dengan mudah dilaksanakan melalui pemanfaatan material berbentuk bola dengan berbagai ukuran dan warna dan ini bukan bahan habis pakai, jadi bersifat tahan lama.Kegiatan laboratorium (praktikum) merupakan salah satu kegiatan pembelajaran Kimia selain "class teaching". Ilmu kimia dibangun dari sebagian besar hasil-hasil penelitian laboratorium, maka kegiatan praktikum merupakan kegiatan pembelajaran yang sangat vital baik dalam memahami maupun mengembangkan ilmu kimia. Oleh karena itu, semakin pembelajaran yang menarik banyak ahli pendidikan kimia di perguruan tinggi (Sawrey, 1990). Melalui pendekatan "problem solving" kenyataannya dapat ditemukan adanya miskonsepsi pada banyak mahasiswa (Nakhleh and Mitchell,1993 dalam Barke, 2009). Dengan kegiatan penyusunan modeling dalam 
acara praktikum, mahasiswa diharapkan dapat mengingat, menata atau mengkontruksi pengetahuannya secara "benar" di dalam sel-sel otaknya, karena pada dasarnya menurut model konstruktivistik, "knowledge is constructed in the mind of the leaner" (Bodner, 1986).

Pada sains, sering ada banyak gagasan yang seringkali disalahtafsirkan. Hal ini dapat menyebabkan pelajar meniru dengan membuat pengertian dari konsep abstrak. Juga karena sains terus menerus mengalami perubahan untuk beradaptasi dengan penemuan dan metode baru. Beberapa miskonsepsi mungkin seharusnya pada ide-ide atau tulisan lama. Karena bentuk dari konsep baru berdasarkan pada bangunan dasar dari sesuatu yang telah lama. Pemahaman yang benar tentang struktur atom melalui praktikum media dan efektifitas media karbon akan meningkatkan kemampuan pengetahuan ruang mahasiswa dan pembelajaran kimia efektif sehingga berbagai miskonsepsi yang terjadi dalam

Kimia akan dapat teratasi dan kemampuan generik kimia mahasiswa terkembangkan. Dengan teratasinya miskonsepsi maka pada pengembangan kimia selanjutnya memudahkan mahasiswa memahami konsep yang abstrak dari Kimia tanpa interpretasi yang salah lebih lanjut kemampuan generik mahasiswa terbekali sehingga dapat digunakan dalam kariernya kelak. Penelitian ini mencoba menyajikan materi pokok bahasan dalam Kimia Anorganik mencakup struktur atom dan Ikatan kovalen pada Karbon. Untuk pemahaman struktur atom ini, mahasiswa tidak perlu melakukan pengamatan langsung pada spektrum atom hidrogen karena tidak tersedianya peralatan. Melalui praktikum ini akan disajikan data panjang gelombang garis-garis spektrum atom hidrogen yang diasumsikan bahwa data tersebut merupakan hasil amatan praktikan sendiri. Kemampuan interpretasi mahasiswa akan dikembangkan dengan menghubungkan data tersebut untuk merumuskan deret Lyman, Balmer dan Paschen. Kegiatan mahasiwa selanjutnya menetapkan $\mathrm{R}_{\mathrm{H}}$ dan diagram transisi-emisi atom Hidrogen menurut Bohr. Untuk lebih terarah disediakan lembar kerja yang harus diselesaikan untuk menguji pemahaman praktikan terhadap materi yang bersangkutan. Acara praktikum berupa penggunaan multimedia interaktif ini belum pernah dilaksanakan, apalagi perkuliahan dengan multimedia dan tampilan mekanika kuantum dan struktur atom serta ikatan kovalensi pada karbon. Untuk keperluan umpan balik disediakan lembar respon mahasiswa dan dievaluasi efektivitas pembelajaran model ini. Dalam Kimia, sering terdapat asumsi yang salah interpretasi tentang konsep yang abstrak seperti struktur zat padat serta karakteristik berbagai unsur kimia. Kimia bersifat tentatif sehingga mengadaptasi metode dan temuan yang baru sehingga beberapa miskonsepsi diakibatkan pendapat kuno yang sudah melegenda.

Permasalahan yang dirimuskan dalam penelitian ini yaitu bagaimana tahapan menurunkan tetapan Rydberg berdasarkan struktur atom Niels Bohr sehingga miskonsepsi dalam Kimia Anorganik teratasi.

Tujuan penelitian ini dimaksudkan untuk memperoleh informasi tentang kemampuan inquiry mahasiswa untuk menelusuri bagaimana para pakar kimiawan menemukan tetapan Rydberg sehingga tidak terjadi miskonsepsi dalam memahami struktur atom khususnya dan Kimia Anorganik umumnya.

\section{Kajian Literatur Metode Praktikum}

Praktikum berasal dari kata praktik yang artinya pelaksanaan senyawa nyata apa yang disebut dalam teori. Praktikum adalah bagian dari pengajaran yang bertujuan agar siswa mendapat kesempatan untuk menguji dan melaksanakan dikeadaan nyata. Pada hakikatnya kegiatan praktikum dapat diartikan sebagai salah satu strategi mengajar dapat menggunakan pendekatan ilmiah terhadap gejala-gejala, baik gejala sosial, psikis, maupun pisik yang diteliti, diselidiki dan dipelajari. Praktikum berisi perintah- perintah yang harus dilakukan sesuai dengan prosedur kegiatan yang dilakukan dan persoalan- persoalan yang dikerjakan atau dijawab oleh siswa" (Azhar, 1993). Praktikum memuat substansi kompetensi yang harus dikuasai oleh siswa, dimana substansi yang akan dipelajari harus ditulis secara lengkap dan disusun secara sistematis, menampilkan substansi kompetensi secara utuh. Dalam penyusunan substansi harus sinkron dengan 
tujuan-tujuan pembelajaran yang telah dirumuskan sebelumnya".(IKIP Yogya,1997; http: // www. yahoo.com // Praktik).

Metode praktikum adalah metode pemberian kesempatan kepada anak didik perorangan atau kelompok, untuk dilatih melakukan suatu proses atau percobaan. Dengan metode ini anak didik diharapkan sepenuhnya terlibat merencanakan praktikum, melakukan praktikum, menemukan fakta, mengumpulkan data, mengendalikan variabel, dan memecahkan masalah yang dihadapinya secara nyata ( Djamarah, 2002 ). Menurut (Roestiyah,1998) metode praktikum adalah salah satu cara mengajar, dimana siswa melakukan suatu percobaan tentang suatu hal, mengamati prosesnya serta menuliskan hasil percobaannya, kemudian hasil pengamatan itu disampaikan ke kelas dan dievaluasi oleh guru. Menurut (Sagala,2005), praktikum adalah percobaan untuk membuktikan suatu pertanyaan atau hipotesis tertentu.

\section{Spektrum Emisi Atom Hidrogen}

Tabung sinar hidrogen merupakan suatu tabung tipis yang berisi gas hidrogen pada tekanan rendah dengan elektroda pada tiap-tiap ujungnya. Jika anda melewatkan tegangan tinggi (katakanlah, 5000 volt), tabung akan menghasilkan sinar berwarna merah muda yang terang.

Jika sinar tersebut dilewatkan pada prisma atau kisi difraksi, sinar akan terpecah menjadi beberapa warna. Warna yang dapat anda lihat merupakan sebagian kecil dari spektrum emisi hidrogen. Sebagian besar spektrum tak terlihat oleh mata karena berada pada daerah infra-merah atau ultra-violet.

Pada foto berikut, sebelah kiri menunjukkan bagian dari tabung sinar katoda, dan sebelah

\section{Spektra Atom}

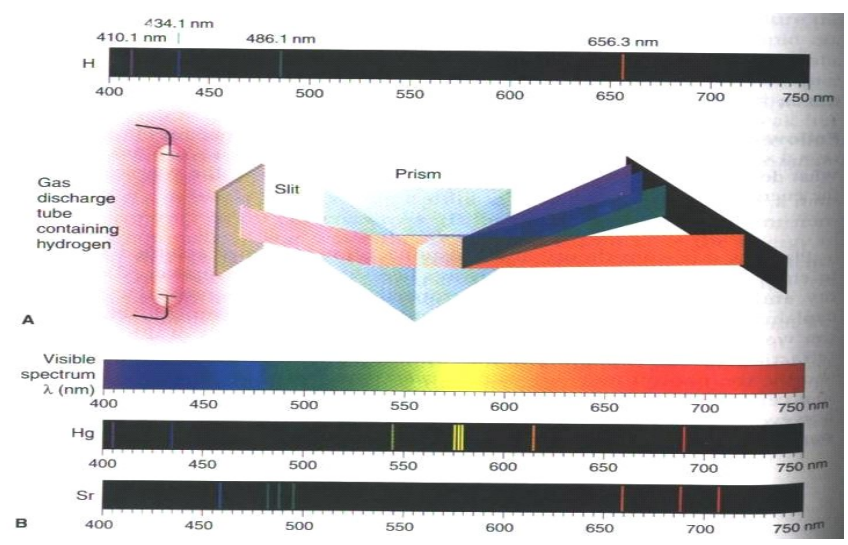

Gambar 1. Spektrum emisi hidrogen hingga UV dan IR

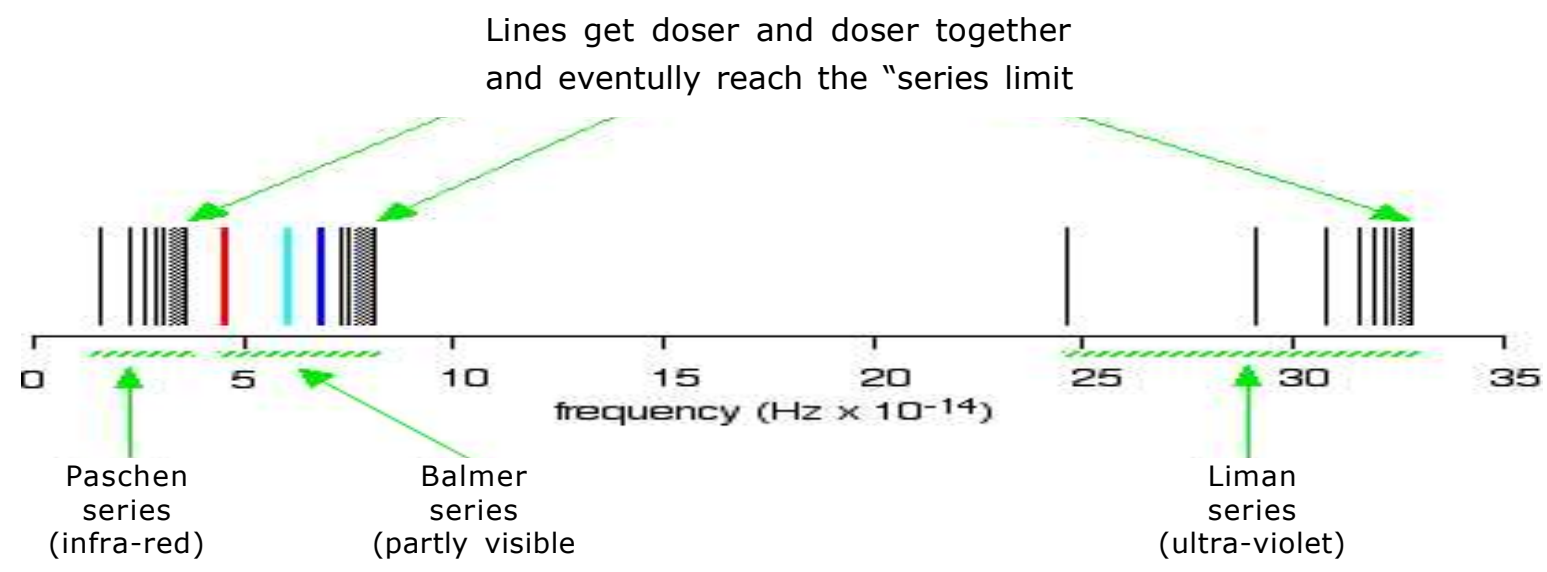

Gambar 2.Deret Lyman 
kanan menunjukkan tiga garis yang paling mudah dilihat pada daerah tampak (visible) dari spektrum. (mengabaikan "pengotor" " biasanya berada di sebelah kiri garis merah, yang disebabkan oleh cacat pada saat foto diambil. Lihat catatan)

Ada lebih banyak lagi spektrum hidrogen selain tiga garis yang dapat anda lihat dengan mata telanjang. Hal ini memungkinan untuk mendeteksi pola garis-garis pada daerah ultraviolet dan infra-merah spektrum dengan baik. Hal ini memunculkan sejumlah "deret" garis yang dinamakan dengan nama penemunya. Gambar di bawah menunjukkan tiga dari deret garis tersebut, deret lainnya berada di daerah inframerah, jika digambarkan terletak di sebelah kiri deret Paschen.

Deret Lyman merupakan deret garis pada daerah ultra-violet. Perhatikan bahwa garis makin merapat satu sama lain dengan naiknya frekuensi. Akhirnya, garis-garis makin rapat dan tidak mungkin diamati satu per satu, terlihat seperti spektrum kontinu. Hal itu tampak sedikit gelap pada ujung kanan tiap spektrum. Spektrum emisi atom hidrogen bebas dalam keadaan tereksitasi Spektrum emisi atom hidrogen bebas dalam keadaan tereksitasi ternyata terdiri atas beberapa set garis-garis spektrum yaitu satu set dalam daerah uv (ultra violet), satu set dalam daerah tampak (visible, artinya tampak oleh mata manusia) dan beberapa set dalam daerah inframerah (IR, infrared) dari spektrum elektro magnetik seperti ditunjukkan oleh Gambar Spektrum ini diperoleh bila cahaya pucat kebiruan dari gas hidrogen yang dipijarkan (artinya teratomisasi) dilewatkan pada sebuah prisma gelas.

Bertahun-tahun para ilmuwan berusaha mendapatkan suatu pola formula yang melukis- kan hubungan antar panjang gelombang ( $\square$ ) garisgaris spektrum atom hidrogen, dan akhirnya pada tahun 1885 J. Balmer (Swiss) berhasil menunjukkan bahwa grafik hubungan antara frekuensi ( $\square$ ) dengan $1 / n 2$ ternyata berupa garis lurus dengan mengikuti rumusan:

$$
\begin{aligned}
& =8,2202 \times 1014\left(1-\frac{4}{n^{2}}\right) \text { Hertz } \\
& \text { (dengan } n=3,4,5,6, \ldots \ldots) \\
& \text { …..... (1.1) }
\end{aligned}
$$

Oleh karena $1 /$ ? $=\bar{v}$ (bilangan gelombang) dan $\square \square=c / \square$, maka persamaan (1.1) dewasa ini sering diungkapkan sebagai berikut:

$$
\begin{aligned}
& \bar{v} ?=1 / ?=109679\left(\frac{1}{2^{2}}-\frac{1}{n^{2}}\right) \mathrm{cm}-1, \\
& \text { (dengan } n=3,4,5,6, \ldots \ldots \ldots . .)
\end{aligned}
$$

Bila elektron menempati orbit pertama $(n=1)$, dikatakan bahwa atom hidrogen dalam keadaan dasar atau ground state karena atom ini mempunyai energi terendah yang umumnya dicapai pada temperatur kamar untuk hampir sebagian besar unsur maupun molekul. Untuk keadaan tingkat energi yang lebih tinggi, yaitu $n$ $>1$ untuk atom hidrogen, dikatakan atom dalam keadaan tereksitasi yang tentunya relatif kurang stabil daripada keadaan dasarnya. Suatu atom atau molekul dapat berada dalam keadaan tereksitasi karena pengaruh pemanasan atau listrik, dan akan kembali ke keadaan dasar dengan memancarkan energi radiasi sebagai spektrum garis yang besarnya sama dengan perbedaan energi antara kedua tingkat energi yang bersangkutan.Dari persamaan (1.10) perbedaan energi, $\square E$, antara dua orbit elektron $n 1$ dan $n 2$

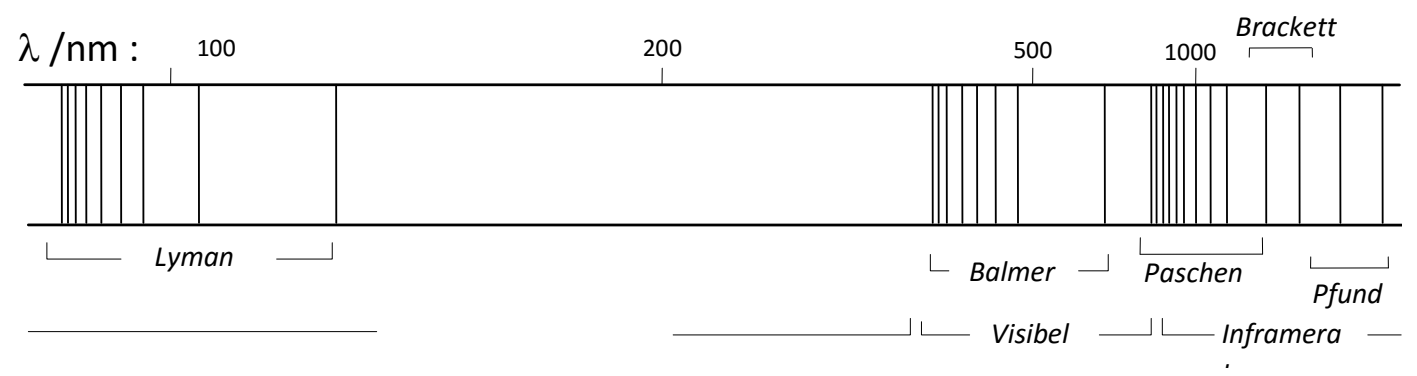

Gambar 3.Spektrum emisi atom hidrogen 
(n2 $>n 1)$ dapat dinyatakan dengan formula:

$$
\square E=\frac{m e^{4}}{8 \varepsilon_{\mathrm{o}}{ }^{2} h^{2}}\left(\frac{1}{n_{1}{ }^{2}}-\frac{1}{n_{2}{ }^{2}}\right)
$$

Dengan mengenalkan besaran energi cahaya menurut Einstein , $\square E=h ?=h c \bar{v}$, ke dalam persamaan (1.11) diperoleh:

$$
\begin{gathered}
\square=\frac{m e^{4}}{8 \varepsilon_{0}^{2} h^{3}}(-) \quad \ldots \ldots \ldots \\
\operatorname{dan} \quad=(-) \quad \ldots \ldots \ldots
\end{gathered}
$$

Persamaan diatas ini jelas identik dengan persamaan Ritz (1.5), sehingga tetapan Rydberg, $R \mathrm{H}$, dapat dihitung secara teoretik yaitu sebesar $109708 \mathrm{~cm}-1$; suatu hasil yang sangat mentakjubkan dibandingkan dengan hasil eksperimen, $R \mathrm{H}=109679 \mathrm{~cm}-1$. Dengan demikian, Bohr mampu mendemonstrasikan perhitungan-perhitungan yang cukup akurat terhadap spektrum garis atom hidrogen.

\section{Miskonsepsi}

Materi pembelajaran atau perkuliahan pada umumnya disampaikan secara lisan - ceramah dan menunjuk pada beberapa buku sebagai daftar pustaka yang disarankan untuk dibaca oleh (maha)siswa. Fungsi guru (dosen) yang dominan yaitu menstransfer konsep-konsep (IPA-kimia) ke dalam diri (maha)siwa. Pelajar benar-benar membangun konsep-konsepnya sendiri. Bangun konsep (kimiawi) yang dimiliki pelajar sering berbeda dari bangun konsep yang dimiliki instruktornya dan yang telah dicoba dipresentasikan. Perbedaan konsep ini oleh para ahli peneliti pendidikan (Nakhleh, 1992) dilukiskan secara variatif sebagai "prekonsepsi", miskon-sepsi", "kerangkakerja alternatif", "pengetahuan anak", "sistem deskriptif pelajar" dan "sistem ekplanatori".

Nakhleh (1992) menyatakan bahwa "misconception means any concept that differs from the commonly accepted scientifict under-standing of the term"; Novak \& Gowin (1986) menyatakan hal yang sejalan bahwa "misconception is the term commonly used to describe an unaccepted (and not necessarily wrong) interpretation of a concept illustrated in the state-ment in which the concept is embedded. Tetapi, van den Berg (1991) menegaskan bahwa dalam bidang ipa, "miskonsepsi" umumnya identik dengan "kesalahan". Jadi, istilah miskonsepsi diartikan sebagai konsep apa saja yang berbeda dari pemahaman ilmiah/saintifik yang umumnya diterima untuk konsep yang bersangkutan. Sekali terintegrasi ke dalam struktur kognitif pelajar, miskonsepsi mempengaruhi proses belajar selanjutnya. Informasi baru yang masuk ke dalam struktur kognitif tidak terkoneksi secara tepat, sehingga terjadilah pemahaman yang lemah atau pemahaman-salah (misunderstanding) terhadap konsep yang bersangkutan. Namun demikian, Novak \& Gowin (1986) berpendapat bahwa makna yang terungkap bukanlah suatu miskonsepsi pada (maha)siswa, melainkan pada makna fungsional. Hal ini didukung oleh kanyataan bahwa miskonsepsi dapat berlangsung dalam kurun waktu cukup lama, namun jika "konsep-konsep penghubung" diintegrasikan ke dalam kerangka konseptual seseorang, ternyata "miskonsepsi" menjadi hilang.

Berbagai usaha telah dilakukan oleh guru (dosen) agar "transfer ilmu" berlangsung dengan "benar" dan lancar, misalnya dengan model-model yang dapat divisualisaikan, demonstrasi dan atau kegiatan laboratorium, dan sebagainya. Namun demikian kenyataan menunjukkan bahwa (maha)siswa tidak hanya mendapat kesulitan dalam belajar kimia melainkan terjadi miskonsepsi. Terjadinya miskonsepsi dalam kimia baik bagi siswa SMU maupun hingga tingkat universitas pada berbagai macam konsep dalam bidang Kimia Dasar, Kimia Anorganik, Kimia Fisik, maupun Ikatan Kimia telah banyak dilaporkan oleh para ahli pendidikan kimia (sebagaimana dinyatakan dalam daftar pustaka ini).

Kesulitan pemahaman konsep-konsep (IPA) kimia tertentu hingga mengakibatkan terjadinya miskonsepsi, barangkali bergantung pada karakteristik konsep-konsep itu sendiri disamping kultur (maha)siswa. Berdasarkan teori konstruktivistik, ilmu pengetahuan dibangun dalam pikiran (maha)siswa (Bodner, 1986); pembentukan konsep dalam pikiran ini dipengaruhi oleh prekonsep yang ada sebelumnya. Dengan demikian "kekeliruan" pembentukan konsep yang ditransfer 
akan menghasilkan konsep yang berbeda ("salah") dari kebenaran konsep yang diharapkan. Tentu saja miskonsepsi diyakini ada hubungannya dengan rendahnya prestasi hasil belajar khususnya jika alat evaluasi belajar benar-benar menuntut kebenaran konsep.

Contoh miskonsepsi yang sering terungkap dalam beberapa pernyataan misalnya: 1) Untuk melihat benda-benda yang yang berukuran mickro dipakai mikroskop, sebab mikroskop memperbesar ukuran benda yang bersangkutan; 2) Kecepatan benda jatuh (bebas) bergantung pada massa (berat) benda yang bersangkutan, makin berat makin cepat jatuhnya; dan 3) Jika sebatang pensil dimasukkan ke dalam air (dalam gelas), maka pensil tersebut akan menjadi bengkok.

\section{Metode Evaluasi Miskonsepsi}

Pendekatan paling umum dilakukan untuk memperoleh informasi perihal miskonsepsi yaitu melalui metode wawancara dan atau "open-ended responses" terhadap pertanyaan atas topik spesifik. Untuk pengajaran dalam klas, pendekatan alternatif dapat menggunakan item yang didasarkan pada format pilihan ganda, namun lebih tepat disertai alasan jawaban termasuk item-miskonsepsi (De Vos \& Verdonk, 1987). Item tes dapat pula disusun dalam bentuk uraian perihal suatu konsep, dengan model isian singkat. Pada dasarnya Novak \& Gowin (1986) menyatakan bahwa terjadinya miskonsepsi dapat dirunut dengan mengidentifikasi adanya "konsep-konsep" penghubung yang hilang.

\section{Miskonsepsi Kimia}

Kesalahan-kesalahan dalam pemahaman konsep (miskonsepsi) kimia akan memberikan penyesatan lebih jauh jika tidak dilakukan pembenahan. Anehnya miskonsepsi itu sering sekali tidak disadari oleh pengajar kimia.(Barke, 2009).

Bahasan mengenai miskonsepsi tentang pelajaran kimia sudah sangat banyak diteliti oleh para guru, mahasiswa, peneliti-peneliti di Indonesia. Namun dari apa yang mereka hasilkan itu sangat sedikit yang dipublikasikan. Entah alasannya apa, mungkin takut dijiplak. Padahal jika hasilnya dipublikasikan tentu akan sangat berguna bagi praktisi pengajar untuk mata pelajaran yang menjadi fokus penelitiannya.
Miskonsepsi siswa sebelum dan sesudah pengajaran formal menjadi suatu perhatian utama diantara para peneliti di Pendidikan Sains karena mereka mempengaruhi bagaimana siswa mempelajari ilmu pengetahuan baru. Memainkan sebuah peranan penting pada pembelajaran berikutnya dan menjadi sebuah halangan dalam memperoleh tubuh yang benar dari pengetahuan. Pada tulisan ini beberapa miskonsepsi siswa tentang ikatan kimia diberikan dalam sebuah literatur yang telah diselidiki dan disajikan. Untuk tujuan ini, suatu literatur yang diperinci melihat tentang ikatan kimia dari data yang telah dikumpulkan dan disajikan menurut masa lalu.

Miskonsepsi kimia adalah sebuah hasil dari Royal Society dari program kimia untuk mendukung pendidikan pada sains kimia. Keith Taber adalah seorang ahli di sekolah RSC pada tahun 20002001. Dia mengembangkan materi ini untuk membantu para guru dalam menggunakan 'konsep alternatif' yang membawa siswa dalam pembelajaran kimia mereka. Dia menyatakan hampir 100 guru pada sekolah tingkat elementry hingga universitas yang membantu mengembangkan dan menilai pendekatan ini pada pembelajaran konsep. Dia merekomendasikan pada bagian I bahwa guru kimia menyelidiki apa yang dipikirkan siswa tentang ide-ide sains sama sebelum latihan dimulai dan mengekplorasi persepsi siswa dari konsep kimia pada sebuah dasar yang berkelanjutan sebagai sebuah bagian penting dari proses belajar mengajar.

Pada sains, sering ada banyak gagasan yang seringkali disalahtafsirkan. Hal ini dapat menyebabkan pelajar meniru dengan membuat pengertian dari konsep abstrak. Juga karena sains terus menerus mengalami perubahan untuk beradaptasi dengan penemuan dan metode baru.

\section{Metode Penelitian \\ Subjek dan Objek Penelitian}

Dalam penelitian ini, mahasiswa Jurusan Kimia yang mengambil mata kuliah Kimia Anorganik Logam tahun akademik Januari-September 2011 merupakan subjek penelitian. Aspek kualitas perkuliahan dan kegiatan praktikum serta prestasi hasil belajar dalam bentuk nilai akhir dan praktikum untuk pokok bahasan terkait dengan materi perkuliahan serta miskonsepsi yang 
teratasi merupakan objek penelitian ini.

Aspek kualitas perkuliahan dan kegiatan praktikum, prestasi hasil belajar dalam bentuk nilai kuliah dan praktikum untuk kajian kemas rapat geometri kristal kimiawi serta miskonsepsi yang teratasi melalui penggunaan produksi media dan multimedia komputer merupakan objek penelitian ini

\section{Setting Penelitian}

Penelitian dilaksanakan di Jurusan Kimia - FMIPAUNIMED, dalam semester genap JanuariSeptember 2011. Kegitan dibagi dalam 2 (dua) tahap, yaitu: a) Mahasiswa secara kelompok diminta melakukan praktikum multimedia Struktur Atom dan Ikatan Kimia dengan petunjuk dari Dosen peneliti dan diminta menjelaskan setiap fenomena yang diamati berdasarkan reaksi-reaksi kimia. Pekerjaan mahasiswa berkelompok tersebut dinilai dengan dibandingkan buatan tim peneliti; dan b) Hasil pekerjaan mahasiswa setelah dipresentasikan dan dibuat laporannya dinilai dan dianalisis terhadap kemampuan penguasaan materi kimia umum berbasis multimedia serta hasilnya direkam.

\section{Rancangan Penelitian}

Penelitian ini menggunakan metode quasi eksperimen dengan normalized gain score comparison group design. Metode perbandingan ini dimodifikasi dari desain eksperimen pretest posttest kelompok eksperimen. Dengan demikian, desain eksperimental penelitian berbentuk:

Dengan $X_{1}$ adalah model praktikum dan kuliah Kimia Anorganik Non Logam dengan multimedia, $\mathrm{X}_{2}$ model regular, $\mathrm{O}$ adalah pretest dan post-test. Subyek penelitian ini adalah mahasiswa semester 2 program S1 jurusan Kimia yang sedang mengikuti mata kuliah Kimia Anorganik terkait struktur atom tahun akademik 2010/2011.

\section{Desain Tahapan Penelitian}

Penelitian ini mengikuti desain tahapan-tahapan sebagai berikut.

Pertama, tahap persiapan.

Tahapan ini mencakup berbagai kegiatan, yaitu: a) penyusunan materi praktikum dalam bentuk lembar kerja yang disusun secara sistematik

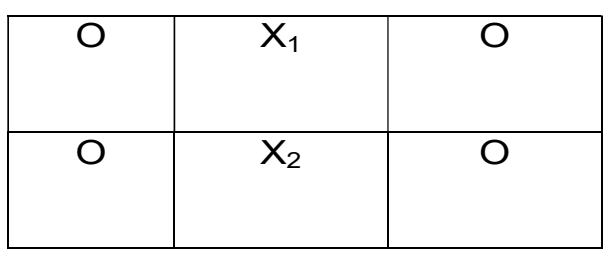

(Sumber: Creswell,JW,1994)

dalam pokok bahasan Struktur Atom dalam hal ini telah selesai ditulis dan siap digandakan; b) pembuatan CD berbasis web dalam bentuk hyperteks untuk perangkat perkuliahan Kimia Anorganik topik struktur atom; c) penyediaan perangkat media grafis seperti kertas foto, plastik printable dan blank cd untuk mendukung pembelajaran; d) penyusunan lembar observasi untuk keperluan monitoring maupun komentar mahasiswa; dan e) penyusunan jadwal pelaksanaan perkuliahan.

Kedua, tahap pelaksanaan.

Tahapan ini (hanya dalam satu siklus) mencakup:a) Pre test; b Pelaksanaan pembelajaran dengan praktikum multimedia Kimia Anorganik topik struktur atom; c) pelaksanaan kegiatan praktikum interaktif yang berupa praktikum multimedia berbagai fenomena, pengisian lembar kerja mahasiswa, dan lembar "observasi" bagi pemonitor (asisten praktikum) dan bagi mahasiswa; d) kegiatan berikutnya yaitu analisis hasil lembar kerja praktikan, dan lembar observasi; dan e) Pos test

Ketiga, tahap akhir

Berupa revisi acara praktikum dan perkuliahan berbasis multimedia yang berkaitan dengan jenis material maupun pola pendekatannya untuk keperluan praktikum dan perkuliahan kimia Anorganik Logam tahun-tahun mendatang serta analisis kemampuan generik kimia berdasarkan postes. Mentabulasi miskonsepsi kimia yang terjaring dan teratasi melalui praktikum tanpa bahan kimia ini.

\section{Metode Pengumpulan dan Analisis Data}

Pelitian ini bersifat deskriptif, yang berusaha memperoleh gambaran pemahaman konsepkonsep struktur atom dan ikatan kimia dalam bentuk prestasi hasil belajar pada diri mahasiswa, 
dan kualitas pembelajaran kegiatan praktikum berbasis multimedia. Oleh karena itu, metode pengumpulan data (nilai) dilakukan secara dokumentatif dan analisis data berupa perhitungan persentase tingkat capaian nilai pokok bahasan yang bersangkutan, dan analisis data perihal kemampuan generik yang terkembangkan dan respon mahasiswa terhadap pelaksanaan kegiatan praktikum tersebut. Pengolahan data selanjutnya dilakukan:1) Analisis kemampuan generik dijaring dari data pre test; 2) Data hasil observasi selama pembelajaran di kelas dan "praktikum" produksi media dan modeling kemas rapat di jadikan bahan penilaian sebenarnya (authentic assesment); 3) Analisis kemampuan generik yang teratasi didasarkan pada data pos test; dan 4) Peningkatan hasil belajar Kimia Anorganik Non Logam di hitung berdasarkan gain ternormalisasi (Meltzer, 2002 dalam Suyanti, 2006):

$$
g=\frac{S_{\text {post }}-S_{p r e}}{S_{\max }-S_{p r e}}
$$

Kategori perolehan skor :

Tinggi : $\mathrm{g}>0,7$

Sedang : $0,3<\mathrm{g}<0,7$; Rendah : $\mathrm{g}<0,3$

\section{Hasil Penelitian dan Pembahasan}

Hasil Belajar mahasiswa setelah melaksanakan praktikum multimedia berbasis inquiry sebagai berikut.
Tabel 1. Prestasi Belajar Mahasiswa

\begin{tabular}{|l|l|l|l|}
\hline Parameter & Pretes & Postes & $\begin{array}{l}\text { Gain ternor- } \\
\text { malisasi }\end{array}$ \\
\hline Rerata & 33,36 & 66,72 & 0,511 \\
\hline SD & 5,74 & 11,48 & 0,129 \\
\hline
\end{tabular}

\begin{tabular}{|l|l|}
\hline Parameter & Prestasi Belajar Mahasiswa \\
\hline Rerata & 82,8 \\
\hline SD & 7,3 \\
\hline
\end{tabular}

Tabel diatas menunjukkan bahwa postes yang diperoleh mahasiswa sudah masuk dalam kategori tinggi dibanding penelitian penggunaan media peraga kemas rapat geometri dengan data sebagai berikut:

\section{Penulusuran Tetapan Rydberg}

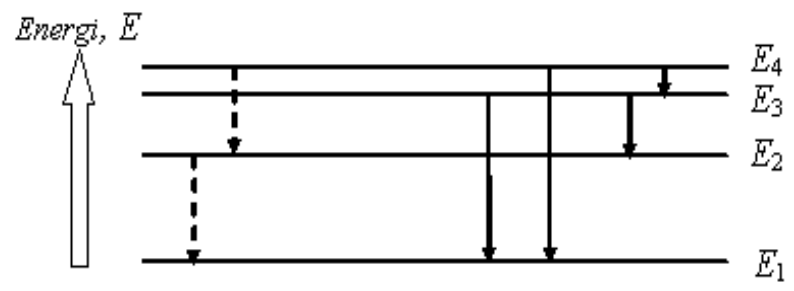

Hubungan Perbedaan tingkat energi:

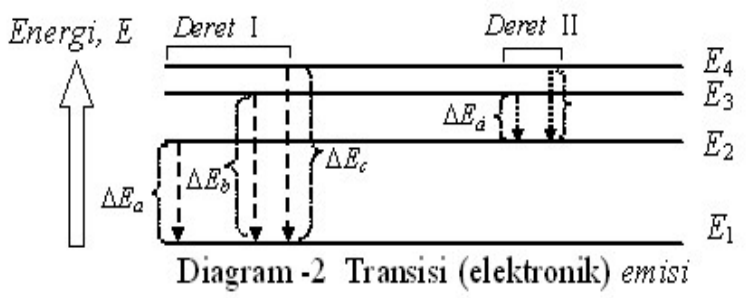

\begin{tabular}{|c|c|c|c|c|c|c|}
\hline \multicolumn{2}{|c|}{$\mathrm{DI} /(\mathrm{nm})$} & Deret & $\mathrm{I} /(\mathrm{nm})$ & õ / cm-1 & \multicolumn{2}{|l|}{ Dõ/(cm-1) } \\
\hline $11-\ln$ & $\ln -|(n+1)|$ & \multicolumn{3}{|c|}{ Deret Lyman } & $\tilde{o}(n+1)$-õn & õn - õ1 \\
\hline & & $L(1)$ & 121,567 & 82259,17 & & \\
\hline & 18,995 & & & & 15233,33 & \\
\hline 18,995 & & $L(2)$ & 102,572 & 97492,49 & & 15233,33 \\
\hline 24,313 & 5,318 & $L(3)$ & & 102823,53 & 5331,04 & 20564,37 \\
\hline & 2,280 & & & & 2468,44 & \\
\hline 26,593 & 1,194 & $L(4)$ & 94,974 & 105291,97 & 1340.57 & 23032,81 \\
\hline 27,787 & 0705 & $L(5)$ & 93,780 & 106632,54 & 80769 & 24373,38 \\
\hline 28,492 & & $L(6)$ & 93,075 & 107440,24 & & 25181,07 \\
\hline 30,392 & & $L(¥)$ & 91,175 & 109679,00 & & 27419,83 \\
\hline
\end{tabular}


Energi ionisasi atom hidrogen yaitu energi yang dibutuhkan untuk mengeluarkan elektron valensi $\left(1 \mathrm{~s}^{1}\right)$, besarnya yaitu $109679 \mathrm{~cm}-1$ Hubungan matematisnya:

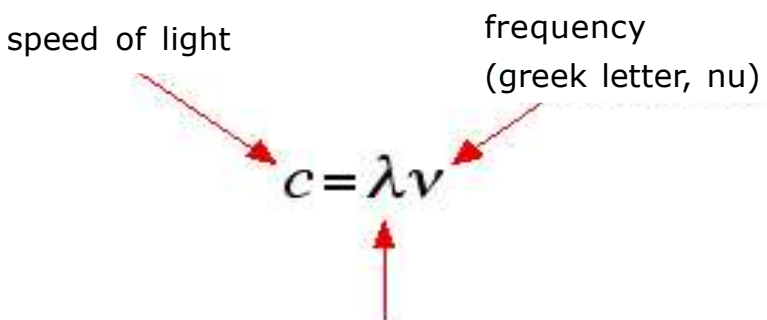

wavelength

(greek letter, lambda
Pengaturan ulang persamaan tersebut akan menghasilkan persamaan baik untuk panjang gelombang maupun frekuensi.

$$
\lambda=\frac{c}{v} \quad v=\frac{c}{\lambda}
$$

Grafik hubungan dengan untuk deret Lyman $\bar{v} / 103 \mathrm{~cm}-1$

Setelah melakukan penelusuran tersebut, persepsi mahasiswa di ases sebagai berikut Grafik yang menunjukkan respon mahasiswa diatas ditampilkan.

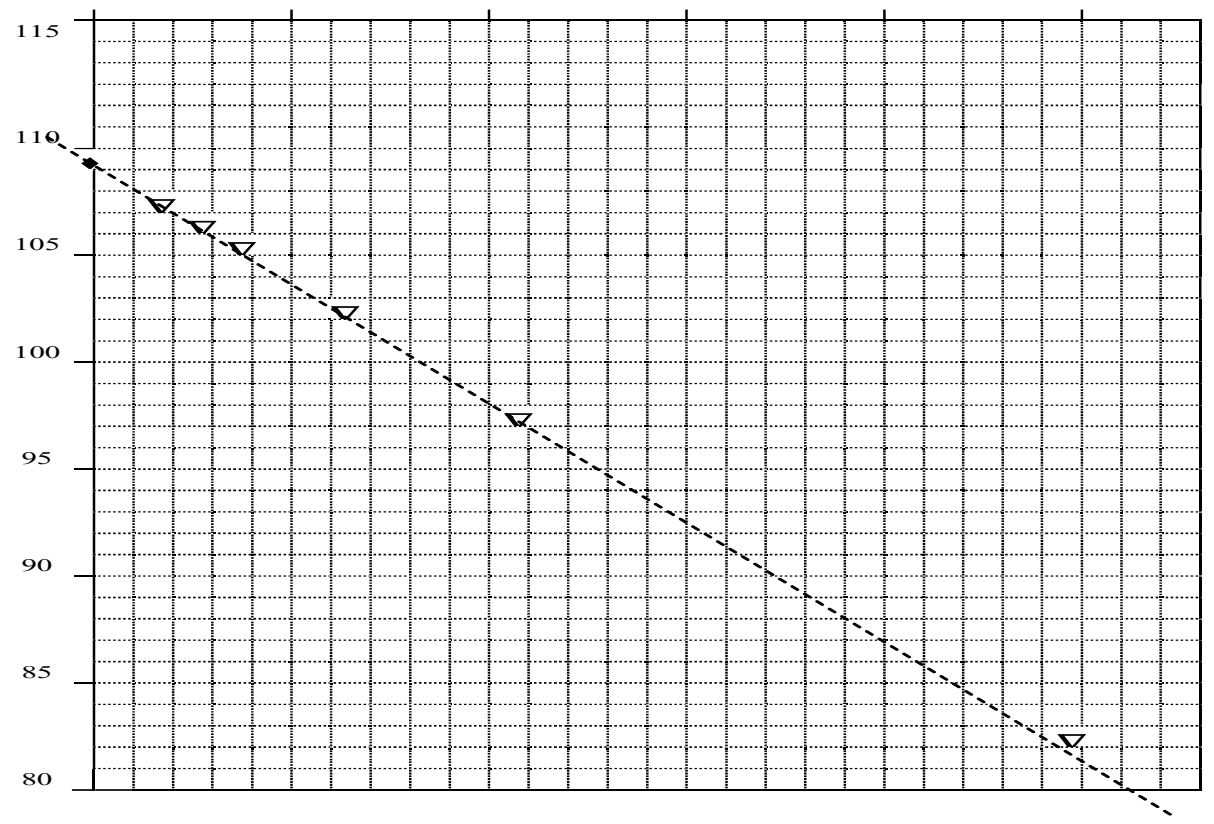

Persamaan garis lurus: $y=109,679 x+109,679$

Titik eksplotasi. $\mathrm{L}(\backsim)=109,679 \mathrm{~cm}^{-1}$ (perpotongan dengan ordinat) Harga batas deret, $L(\backsim)=109,679 \mathrm{~cm}^{-1}$ (dari tabel)

Tabel 2. Respon mahasiswa terhadap praktikum dengan alat peraga

\begin{tabular}{|l|l|l|}
\hline \multirow{2}{*}{ No } & Aspek yang dinilai & Skor \\
\cline { 3 - 3 } & Tampilan alat peraga & $(\%)$ \\
\hline 2 & Ukuran alat peraga & 92 \\
\hline 3 & Bentuk alat peraga & 91 \\
\hline 4 & $\begin{array}{l}\text { Relevansi/kesesuaian alat peraga dengan materi pokok } \\
\text { bahasan }\end{array}$ & 92 \\
\hline 5 & $\begin{array}{l}\text { Kejelasan hubungan alat peraga dengan pemahaman } \\
\text { Anda terhadap materi pokok bahasan }\end{array}$ & 92 \\
\hline 6 & Peran dosen dalam penampilan alat peraga & 83 \\
\hline 7 & Respon mahasiswa terhadap penggunaan alat peraga & 94 \\
\hline 8 & Aktivitas Mahasiswa & 94 \\
\hline
\end{tabular}




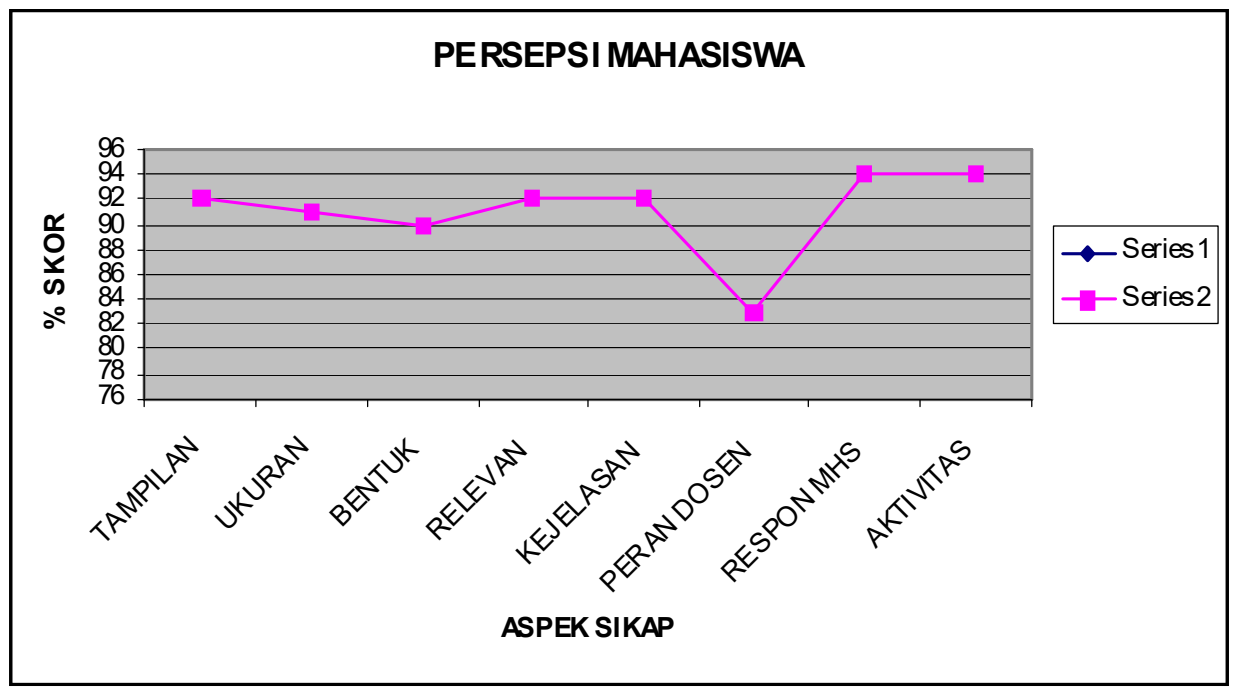

Grafik 3. Respon mahasiswa terhadap praktikum dengan media

Dari grafik diatas dapat diketahui bahwa siswa sangat antusias dengan media peraga yang mereka buat dan digunakan untuk memecahkan masalah bagaimana menghitung energi emisi pada berbagai deret spectrum: Lyman, Balmer, Pascen dan Pfund.

\section{Pembahasan}

Mengacu pada hipotesis tindakan "Implementasi perkuliahan dan praktikum Struktur Atom secara interaktif berbasis multimedia yang mampu mengatasi miskonsepsi dan meningkatkan kemampuan generik kimia mahasiswa, maka dilihat dari prestasi belajar pada table 1 rerata prestasi mahasiswa sudah termasuk kategori baik. Ditinjau dari kemampuan inquiry mendapatkan tetapan Rydberg maka berbagai miskonsepsi dalam analisis secara mendalam terhadap spektrum atom hidrogen yang merupakan suatu langkah awal yang paling fundamental dalam usaha elusidasi struktur elektronik suatu atom telah teratasi (Sugyarto,2011) Hal ini memberi pengalaman kepada mahasiswa menelusuri kerja para ilmuwan kimia. Bertahun-tahun para ilmuwan berusaha mendapatkan suatu pola formula yang melukiskan hubungan antar panjang gelombang $(\lambda)$ garis-garis spektrum atom hidrogen, dan akhirnya pada tahun $1885 \mathrm{~J}$. Balmer (Swiss) berhasil menunjukkan bahwa grafik hubungan antara frekuensi $(\lambda)$ dengan $1 / n 2$ ternyata berupa garis lurus dengan mengikuti rumusan: $\lambda=8,2202 \mathrm{x}$
$1014(1$ - ) Hertz (dengan $n=3,4,5,6, \ldots \ldots$ ) ........ (1.1)

Oleh karena $1 / \lambda=\bar{v}$ (bilangan gelombang) dan $\lambda \lambda=c / \lambda$, maka persamaan (1.1) dewasa ini sering diungkapkan sebagai berikut:

$$
\overline{\mathrm{v}} \lambda=1 / \lambda=109679\left(\frac{1}{2^{2}}-\frac{1}{n^{2}}\right) \mathrm{cm}^{-1}, \text { (dengan } n
$$

$=3,4,5,6, \ldots \ldots \ldots)$

Dalam kurun waktu kira-kira 40 tahun kemudian akhirnya ditemukan beberapa deret garis lain yang mirip dengan deret Balmer. Deret baru ini kemudian diberi nama sesuai dengan penemunya, yaitu Lyman (1906) yang terpencar pada daerah ultraviolet, Paschen (1908) yang terpencar pada daerah iframerah-dekat, Brackett (1922) yang terpencar pada daerah inframerah, dan deret) Pfund (923, yang terpencar pada daerah inframerah-jauh. Dari aspek persepsi mahasiswa terhadap kegiatan praktikum multimedia ini menunjukkan sikap positip yang berarti media pembelajaran ini sangat membantu pemahaman konsep yang benar tentang Struktur Atom pada mahasiswa yang pada gilirannya akan membekali berbagai kemampuan generic kimia seperti pengamatan tak langsung dan logical frame juga logical inference dan pemodelan. 


\section{Simpulan dan Saran Simpulan}

Kemampuan interpretasi mahasiswa terkembangkan dengan menghubungkan data panjang gelombang garis-garis spektrum atom hidrogen yang diasumsikan bahwa data tersebut merupakan hasil amatan praktikan sendiri guna merumuskan deret Lyman, Balmer dan Paschen. Kegiatan mahasiwa selanjutnya menetapkan $R_{H}$ dan diagram transisi-emisi atom Hidrogen menurut Bohr. Untuk lebih terarah disediakan lembar kerja yang harus diselesaikan untuk menguji pemahaman praktikan terhadap materi yang bersangkutan. Acara praktikum berupa penggunaan multimedia interaktif ini didukung dengan multimedia dan tampilan mekanika kuantum dan struktur atom. Dengan praktikum ini maka miskonsepsi terkait struktur atom teratasi dan hasil belajar Kimia Anorganik mahasiswa mencapai rerata 82.78. Sikap Mahasiswa terhadap kegiatan praktikum tersebut sangat positip ( $92 \%$ responsive).Dengan teratasinya miskonsepsi tersebut maka prestasi belajar mahasiswa meningkat signifikan. Kemampuan generik yang terkembangkan antara lain kemampuan pengamatan tak langsung guna memahami penentuan tetapan Rydberg sebagaimana dilakukan oleh para saintis.

\section{Saran}

Berdasarkan kesimpulan hasil penelitian maka disarankan sebagai berikut:

Pertama, Pengembangan (try out) penelusuran mendapatkan pengetahuan (construct) seperti tetapan Rydberg akan memberikan pengalaman belajar yang bermakna bagi mahasiswa. Kedua, penerapan strategi pembelajaran inquiry termodifikasi dan terbimbing sangat tepat dalam menggunakan media peraga dan aplikasi numerasi dalam perkuliahan terintegrasi guna mengatasi miskonsepsi dalam Kimia Anorganik.

\section{Pustaka Acuan}

Azhar, L. 1993. Proses Belajar Mengajar Pola CBSA, Usaha Nasional, Surabaya.

Barke, Al Hazhari, Siretsi Barek. 2009. Misconceptions in Chemistry, Springer, Berlin Heidelberg.

Bodner, G. M., "Constructivism: A Theory of Knowledge", Journal of Chemical Education, 1986, 63, 873 878.

Djamarah, Syaiful Bahri. 2002. Psikologi Belajar, Rineka Cipta, Jakarta

"IKIP Yogya. 1997. http: // www. yahoo.com // Praktikum (Accessed February 2011).

Roestiyah, N.K. 1998. Strategi Belajar Mengajar, Penerbit Rineka Cipta, Jakarta.

Creswell W. John. 1994. Research Design, Sage Publications, New Delhi

Sawrey, B. A., "Concept Learning versus Problem Solving", Journal of Chemical Education, 1990, 67, $253-254$

Suyanti D Retno. 2006. Pembekalan Kemampuan Generik Bagi Calon Guru Melalui Pembelajaran Kimia Anorganik Berbasis Multimedia Komputer, Disertasi, SPS UPI, tidak diterbitkan.

Sugyarto. H K., dan Suyanti; DR. 2011. Kimia Anorganik non Logam, Graha Ilmu, Yogyakarta.

Nakhleh, M.B. 1992. "Why Some Students Don't Learn Chemistry : Chemical Misconceptions". Journal of Chemical Education, 69, 191-196.

Novak, J. D., and Gowin, D. B. 1986. Learning How to Learn, Cambridge, Cambridge University Press. Peterson, R.F., and Treagust, D.F. 1989 "Grade-12 Students' Misconseptions of Covalent Bonding and Structure". Journal of Chemical Education , 66, 459-460.

Sagala, Saiful. 2005. Konsep dan Makna Pembelajaran, Alfabeta, Bandung.

De Vos, W., and Verdonk, A.H. 1987. "A New Road to Reactions", The

Substance and Its Molecules. Journal of Chemical Education, 64, 692-694. 